Article

\title{
Novel Design for Thermal Management of PV Cells in Harsh Environmental Conditions
}

\author{
Nasser Ahmad, Amith Khandakar *, Amir El-Tayeb, Kamel Benhmed, Atif Iqbal(D) \\ and Farid Touati \\ Electrical Engineering Department, College of Engineering, Qatar University, Doha 2713, Qatar; \\ na1107575@student.qu.edu.qa (N.A.); ae1104530@student.qu.edu.qa (A.E.-T.); \\ kamelbenhmed@gmail.com (K.B.); atif.iqbal@qu.edu.qa (A.I.); touatif@qu.edu.qa (F.T.) \\ * Correspondence: amitk@qu.edu.qa; Tel.: +974-4403-4235
}

Received: 13 October 2018; Accepted: 19 November 2018; Published: 21 November 2018

\begin{abstract}
The abundance of solar energy is a blessing in the Arabian Peninsula, where more than $2000 \mathrm{kWh} / \mathrm{m}^{2}$ density has been recorded annually. This has resulted in sincere consideration of PV harvesting in the energy matrix and smart grid. However, artefacts such as degradation of PV efficiency due to the high temperature effect have to be addressed. This paper presents a novel design of a PV cooling system using water to mitigate the effect of high temperature. Several experiments have been conducted, and the results have been analyzed. It has been found that the collected water from the panel after $40 \mathrm{~min}$ of cooling gained a temperature of $10^{\circ} \mathrm{C}$ approximately, during December 2016. Eventually, the efficiency was improved by $10.35 \%$ (without using MPPT) using water at ambient temperature $\left(24{ }^{\circ} \mathrm{C}\right)$ compared to the non-cooled panel. Moreover, the temperature of the panel during solar peak hours dropped from $64.3^{\circ} \mathrm{C}$ to $32^{\circ} \mathrm{C}$ and from $59{ }^{\circ} \mathrm{C}$ to $27^{\circ} \mathrm{C}$ in $3 \mathrm{~min}$ for the back and front surface, respectively. These results, which are the first of their kind in Qatar, constitute good incentives and pave the way for further investigation to enhance PV efficiency in harsh environments. This would be of paramount significance, especially for scaling up PV deployment, as is planned in Qatar and GCC countries in their 2030 vision.
\end{abstract}

Keywords: water cooling; heat transfer; efficiency; photovoltaic; overheating; renewable energy

\section{Introduction}

Solar irradiance reaching the Arabian Peninsula lands is rated at more than $2000 \mathrm{kWh} / \mathrm{m}^{2}$ annually [1]. In addition, Photovoltaic (PV) technology is becoming more preferred than any other source of renewable energy (e.g., wind energy), because it is static, free of noise, and requires relatively lower maintenance cost. Moreover, the drop in the capital cost, being free of pollution while in operation, and being sustainable have gathered further attention in the last few years. However, in hot regions, PV efficiency drops considerably, for instance in Qatar, as the temperature reaches $40{ }^{\circ} \mathrm{C}-50{ }^{\circ} \mathrm{C}$ during summer [1]. Quantitatively, due to the heating effect, the efficiency drops by $0.1 \%-0.5 \%$ for each $1{ }^{\circ} \mathrm{C}$ gained by the cell surface, depending on the manufacturing technology [2,3]. In Qatar, during the summer season, the surface temperature of the PV panel reached around $80^{\circ} \mathrm{C}$, which could be the same case for the Arabian Gulf and other Middle East countries [4].

Practically, PV converts some fraction of irradiance into energy, and the rest is reflected or converted into heat on the module. For example, the average efficiency of mono-crystalline silicon solar cells falls between $14 \%$ and $17 \%$, depending on the technology and manufacturer [5]. Technically, PV technology utilizes semi-conductors as cells to convert solar energy into electrical energy. Moreover, every cell has series and parallel resistances; due to high temperature, the series resistance increases, while the shunt resistance drops. The increase in series resistance leads to higher 
voltage drops, which reduce the output voltage, and similarly, a drop in parallel resistance allows more current to flow through it. Consequently, the output power drops due to the high temperature $[3,6,7]$. High temperature does not affect the PV efficiency only, but also affects the lifetime of the panel [8].

To improve the PV efficiency, many studies have been conducted to cool down the PV surface. A multi-crystal PV of $60 \mathrm{~W}$ was used with a variable resistor to find the I-V characteristic curve and for cooling at a water flow of $5 \mathrm{~L} / \mathrm{min}$, to observe the efficiency of the panel at the Hashemite University, Jordan, under desert climatic conditions. An increase in output power of the system was found in the range of $4-10 \%$ due to front surface cooling [5]. A study was conducted at the German University in Cairo on a system that had six PV panels rated at $185 \mathrm{~W}$ per panel, and a pump was used to be switched on for 5 min at solar peak (between 11:00 and 14:00); the efficiency was increased from $10.7 \%$ to $12.0 \%$, and the temperature dropped from $47^{\circ} \mathrm{C}$ to $36^{\circ} \mathrm{C}$. This study implies that after $5 \mathrm{~min}$ of cooling at the maximum temperature of the day, the efficiency was improved by $10.8 \%$ and the temperature dropped by $11^{\circ} \mathrm{C}$ [7]. However, it was noted that the system returned to operating at the pre-cooling state within $15 \mathrm{~min}$.

Though there are many approaches, where solutions similar to solvents for cooling purposes have been used [9-11], the focus of the paper is to use water, as it is readily available, and the hot water collected later could be used for other purposes, unlike solvents. Nonetheless, considering solvent cooling is an opportunity that could be investigated further. It was further verified in previous studies that cooling by water is the most efficient way for cooling PV cells $[7,12,13]$. In addition, water is a more effective coolant than air [14]. The Sun-tracking technique would not be an effective method if it were applied in summer compared to water-cooling. Moreover, water flow on the active surface can reduce reflection losses of the light, because the refractive indexes of air and glass are 1.0 and 1.5, respectively, whereas the water refractive index is 1.3, which falls between air and glass [3]. Furthermore, cooling by water can increase the lifetime of cells and eliminate debris spots, which can destroy the cells due to the distribution of a non-uniform nature of temperature on the panel [3,5]. An experiment was conducted in University Politehnica of Bucharest to observe the cooling of the front surface of the PV. By having a water flow at a rate of $2 \mathrm{~L} / \mathrm{min}$ at $24{ }^{\circ} \mathrm{C}$, the temperature was dropped from $48{ }^{\circ} \mathrm{C}$ to $35.5^{\circ} \mathrm{C}$ and output power was boosted from $73.0 \mathrm{~W}$ to $76.5 \mathrm{~W}$. That means maximum efficiency was increased by $4.575 \%$. However, panel efficiency dropped back to its pre-cooling state in less than 10 min after cooling was switched off [3].

In the United Arab Emirates, four identical mono-crystalline PV modules of 32 cells, each rated at $140 \mathrm{~W}$ peak output, using a commercial PV tracker were monitored under different water temperatures by an intermittent cooling technique. The modules were in Abu Dhabi $\left(24.43^{\circ} \mathrm{N}, 54.45^{\circ} \mathrm{E}\right)$, at a tilt angle of $24.5^{\circ}$ with respect to the horizontal ground plane and were above the ground by an altitude of $15 \mathrm{~m}$. A Polyvinyl Chloride (PVC) tube was placed on the upper edge of the panel to cool the active surface uniformly and to minimize the thermal contact resistance between water particles and solar cells. At ambient temperature, the water temperature was between 38 and $39^{\circ} \mathrm{C}$. Electrical efficiency was boosted by $18.18 \%, 19.2 \%$, and $24 \%$ when cells were cooled with water at ambient temperature (38-39 $\left.{ }^{\circ} \mathrm{C}\right), 25^{\circ} \mathrm{C}$, and $8{ }^{\circ} \mathrm{C}$, respectively [15]. Moreover, the experiment showed that the intermittent cooling method was more effective than continuous cooling, even using un-chilled water. However, the system used to operate at its pre-cooling efficiency within $15 \mathrm{~min}$ after switching off the cooling system, which worked for 3-5 min.

In the United Arab Emirates, it was experimentally stated that through cooling, peak output power of $0.5 \mathrm{~W}$ was gained for a reduction of every ${ }^{\circ} \mathrm{C}$ in the cooling water below ambient air temperature. Two identical PV modules were used, each having a rated output of $140 \mathrm{~W}$ peak facing south, and tilted at $24.5^{\circ}$, with respect to the horizontal ground plane, in Abu Dhabi. The cooling setup was water flowing on the cells uniformly through an outlet pipe that was placed on the upper edge of the module and recirculated by gravity through a trough to the second reservoir. A PV analyzer was used at the output to maximize the output power; therefore, electrical efficiency was increased by $24 \%$ when cells were cooled by water at a temperature of $3{ }^{\circ} \mathrm{C}$ [16]. Moreover, the intermittent cooling 
technique was applied as $5 \mathrm{~s}$ on and two minutes switched off, which saved $96 \%$ of water consumption relative to continuous cooling. However, under $3 \mathrm{~min}$ after switching off cooling, the efficiency of the cell dropped back to its pre-cooling state.

Despite the untapped solar irradiance in the region, artefacts like high ambient temperature for a large duration in a year along with a dusty environment degrade the energy yield of PV systems. Hence, to improve the efficiency of the conversion, it is significant to develop a system that can cool down the system periodically. As the objective is to check the PV panel performance with the novel cooling technique, three different experiments were done on a single PV at different times. Even though it is obvious that cooling the back surface will have better performance, there has been no quantitative study on this so far. In this study, a mono-crystalline panel setup was used, which was available in the research facilities. Nevertheless, similar or even more pronounced results could be expected if poly or amorphous PV cells were used, because it was seen in another study that polycrystalline solar cells are more prone to temperature effects than mono-crystalline [4]. Overall, cooling by water has several advantages, such as collecting more irradiance due to refraction through water, dropping the panel temperature, removing light pollutants from the surface, and providing hot water.

To the best of the author's knowledge, the cooling system proposed in this work differs from other reported cooling approaches. In previous works, researchers used backside pipes, water spraying nozzles, and water immersion of the panels. In all these cases, either water was wasted or the aspect of the amount of heated water temperature was not studied. Moreover, in this study, the authors eliminated the resistance between the coolant (i.e., water) and the panel by just covering the back surface completely and making it, for the first time, a water conservation reservoir, which is considered as novel, but not innovative. The experiment is a proof-of-concept that should lead to quantifying improvement in energy conversion by water-cooling. The rest of the paper is organized as follows: Section 2 describes the methodology of cooling proposed by the authors; Section 3 presents and discusses the results; and Section 4 concludes the work.

\section{Methodology of Cooling}

The proposed system is shown in Figures 1 and 2, and as shown in Figure 1, the proposed design comprised a 250-L reservoir, DC pumps with a rated flow of $20 \mathrm{~L} / \mathrm{min}$, PVC tubes, PVC pipes, and electric valves.

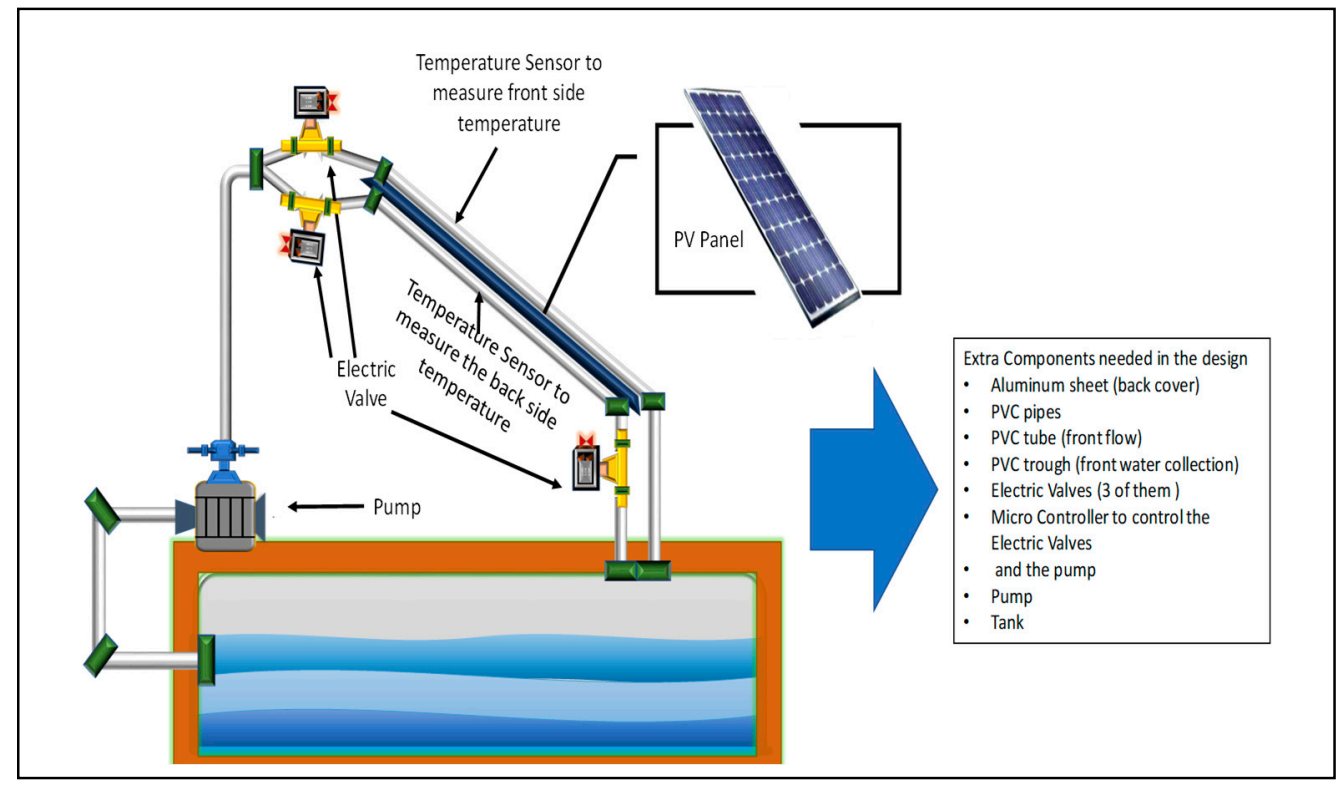

Figure 1. The configuration of the experimental setup. 
In Figure 2, to eliminate physical resistance between the coolant and cells, an aluminum sheet of $4 \mathrm{~mm}$ was utilized to cover the backside of the panel with a capacity of $19 \mathrm{~L}$. Water was in direct contact with the panel to ensure a good heat transfer from the panel to the water. A cylindrical PVC tube was placed on the upper edge of the panel to allow water flowing on the front surface uniformly, where the trough at the bottom accumulated water to took it back to the tank for recycling. The system was automatically controlled by the Arduino microcontroller kit. The microcontroller controlled the working of the DC pump and the electric valves. The electric valves were connected to the input and output of the PVC pipes connected to the backside of the PV panel; refer to Figure 1. These valves were controlled such that water was allowed to stay for a specific amount of time on the backside of the panel. The electric valve connected to the input of the PVC pipes on the front side of the PV panel was just to control the flow of water on the front side of the panel.

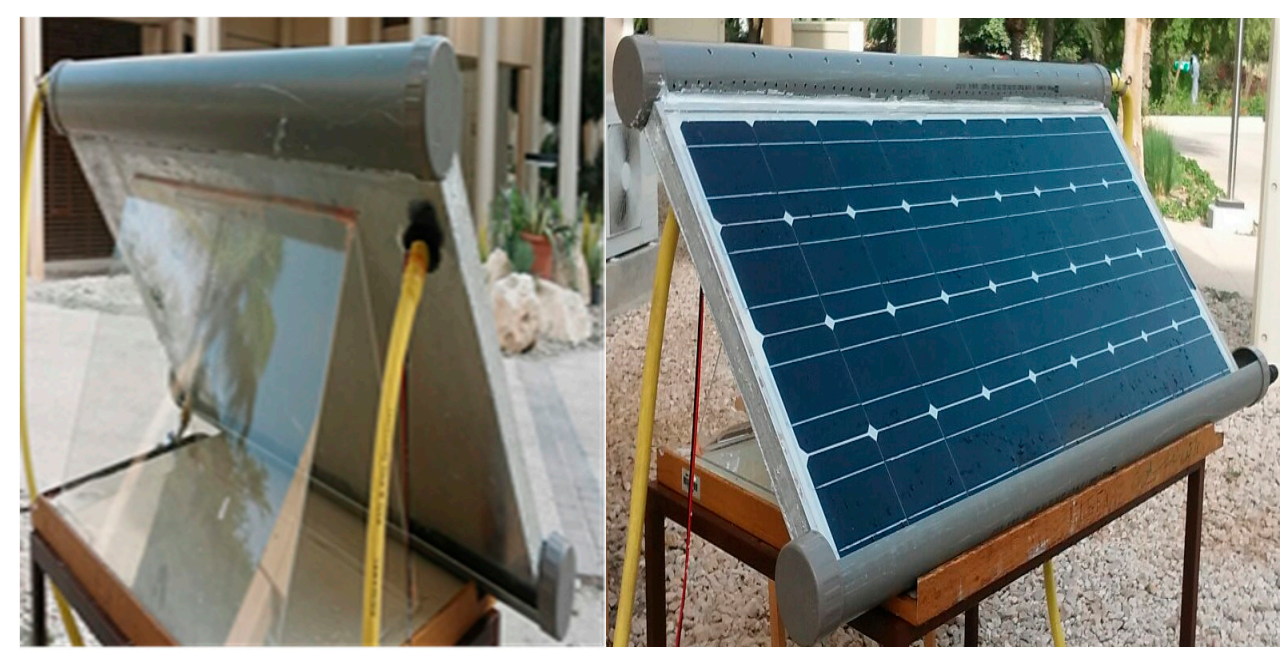

Figure 2. Backside surface and active (front) surface cooling design of PV.

Signals were adapted to the needed power from the electric valves, pump, and relays. LabVIEW software was used for monitoring, data logging, and to modify the cooling mode as per the command from the user. Consequently, the proposed method avoided the appearance of hot spots, because it cooled the panel uniformly on both sides. Further data about the panel monitoring system and climatic conditions of Qatar can be found in a previously-published article [4]. It is noteworthy that the experiments were focused on the hottest three-hour interval, where temperature effects are highest [4]. This is also verified by previous studies where this particular interval corresponded to simultaneously the peak temperature, peak PV power, and peak energy demand in Qatar [4].

In this study, two identical mono-crystalline solar modules were tilted at an angle of $47^{\circ} \pm 2^{\circ}$ with respect to horizontal ground plane at $190^{\circ}$ facing south. The results were from mono-crystalline PV panels, but this was expected to behave similarly or better if poly or amorphous PV cells were used, as polycrystalline solar cells are more prone to the temperature effect than mono-crystalline solar cells [4]. The experiment was conducted from 11:00-14:00 on Tuesday 27 December 2016 at Qatar University to investigate the effect of the cooling on the panel performance, then the data were obtained and analyzed. To read the voltage and current for output power calculations, both PV panels were loaded with a constant resistance of $10 \Omega$. The ambient temperature was between 28 and $31^{\circ} \mathrm{C}$. Modules' data are given below in Table 1, and uncertainty of devices (equipment and sensors) is given in Table 2. 
Table 1. Mono-crystalline panel's parameters.

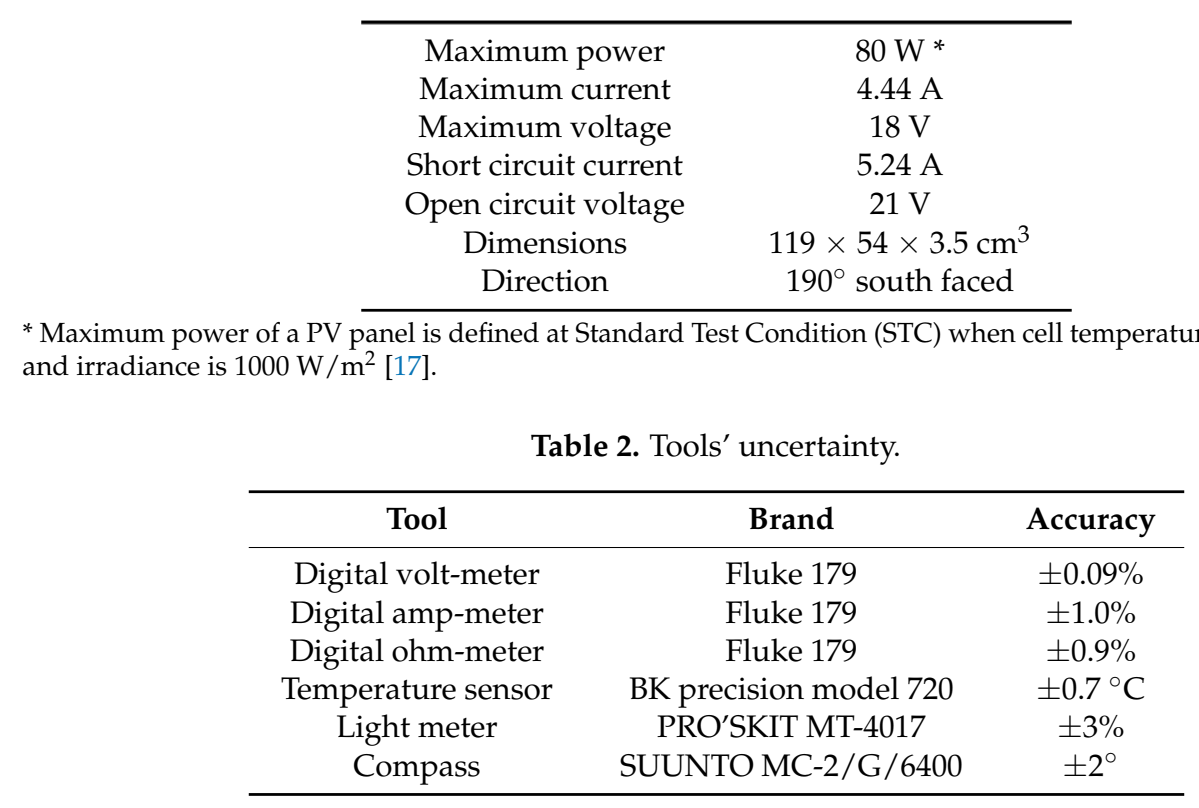

\section{Results and Discussion}

In Figure 3, both panels were kept under irradiance of the Sun for an hour before collecting the readings. The initial temperature of the water in the reservoir was about $24{ }^{\circ} \mathrm{C}$. Cooling of the active (front surface) surface started at 11:10 for $3.2 \mathrm{~min}$, and the output power improved until 11:13. As the cooling stopped, the panel power started to decay gradually due to the increase in cells' temperature. Output power of the panel at 11.13 was approximately $10.35 \%$ higher compared to the non-cooled panel.

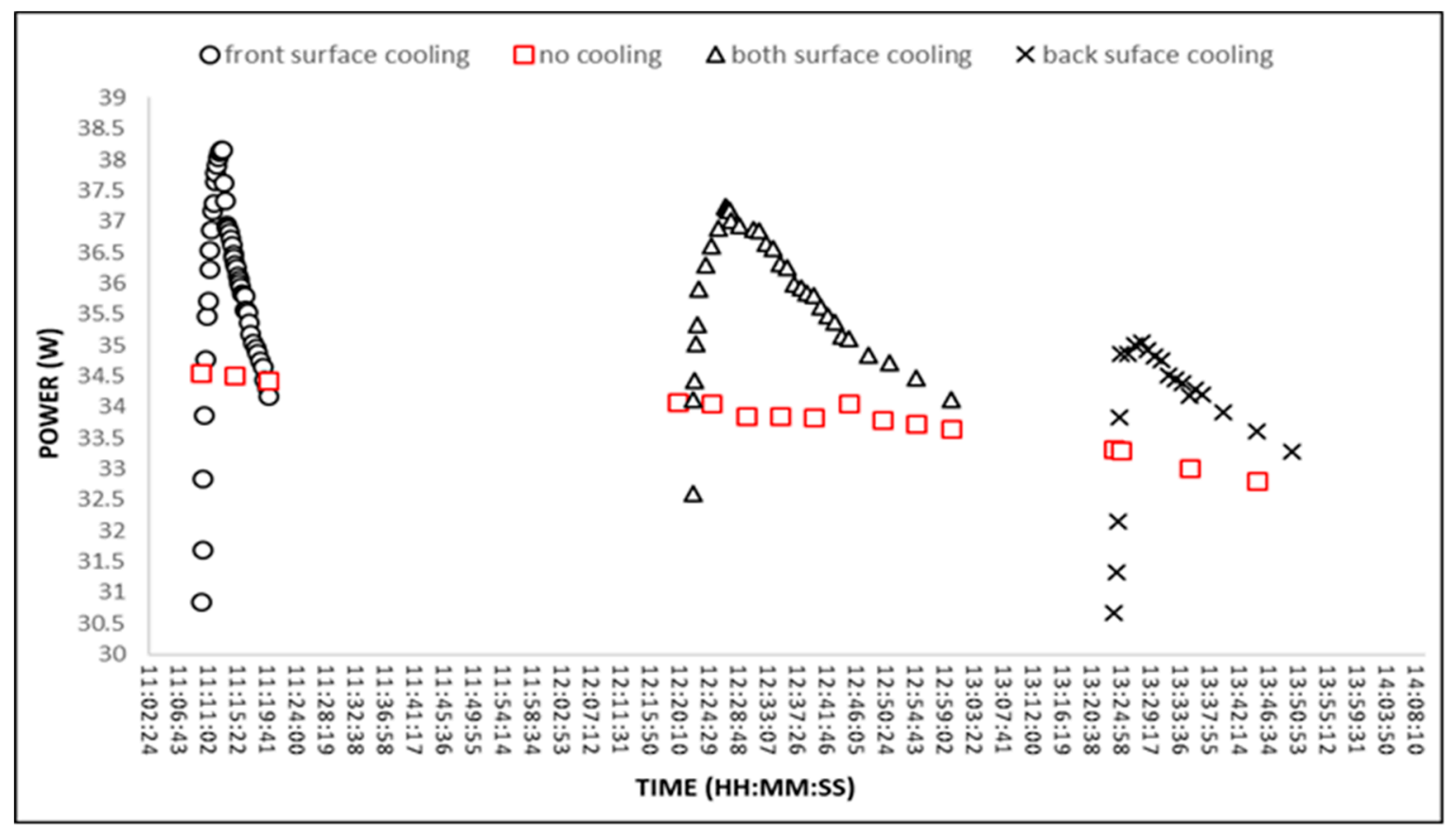

Figure 3. The output power of PV vs. time for front and back surface cooling.

As shown in Figure 4, the temperature of the panel dropped from $64.3^{\circ} \mathrm{C}$ to $32{ }^{\circ} \mathrm{C}$ and $59{ }^{\circ} \mathrm{C}$ to $27^{\circ} \mathrm{C}$ in $3 \mathrm{~min}$ for the back and a front surface, respectively. Moreover, the average output power was increased by $4.0 \%$ for $10 \mathrm{~min}$ compared to the normal panel. 


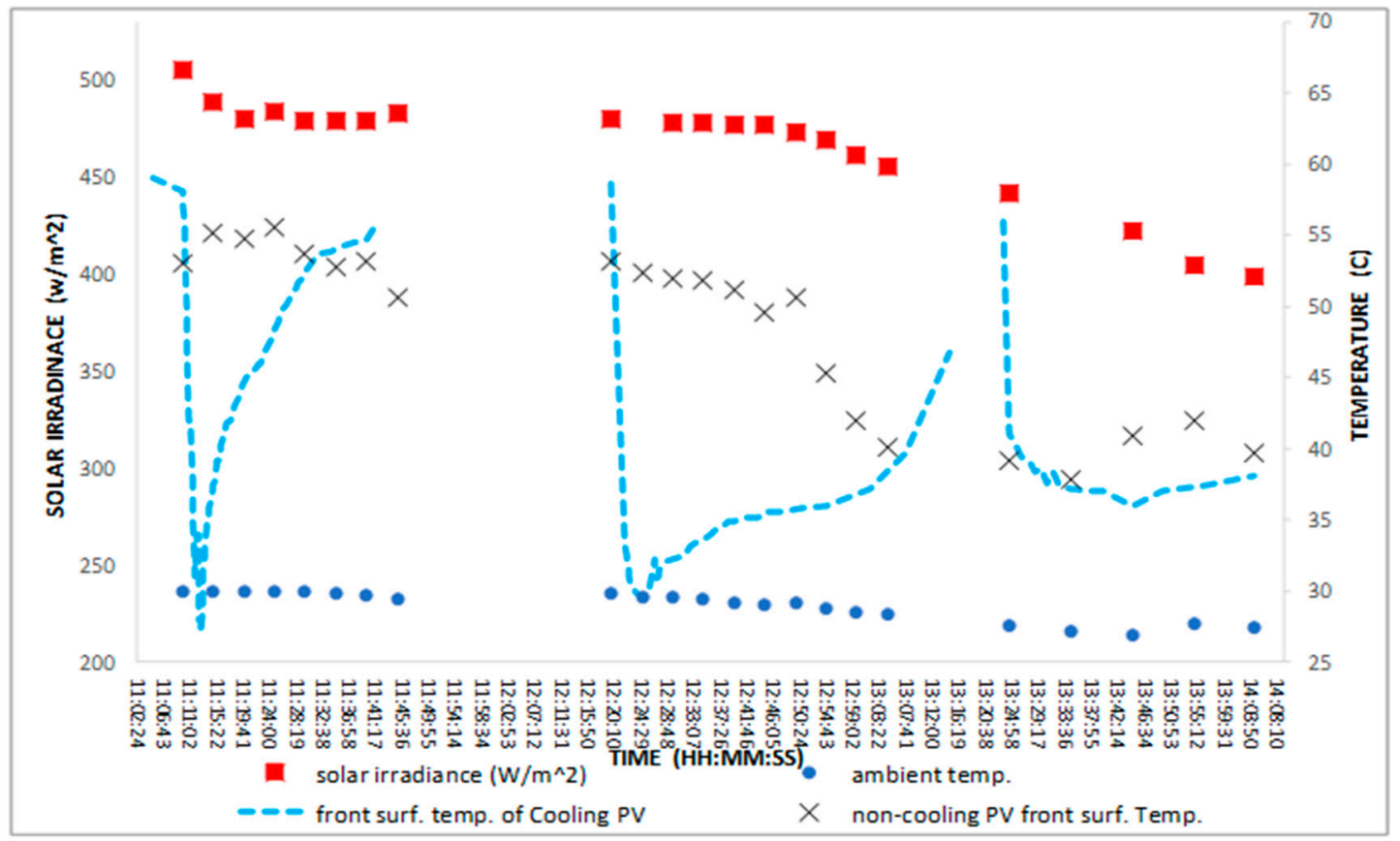

Figure 4. Solar Irradiance, ambient temperature, and temperature of the cooled and non-cooled panel vs. time.

In Figure 3 at 12:22, cooling for both surfaces of the module was started. The backside container was filled with water for a minute, and front surface cooling was switched on for a minute after $3 \mathrm{~min}$. At 12:27, the maximum improvement in power reached $8.55 \%$. In addition, it was recorded that the panel temperature dropped from $64{ }^{\circ} \mathrm{C}$ to $32{ }^{\circ} \mathrm{C}$ and $59{ }^{\circ} \mathrm{C}$ to $31^{\circ} \mathrm{C}$ in $5 \mathrm{~min}$ for the back and front surface, respectively. Moreover, the average output power was increased by $5.6 \%$ for $40 \mathrm{~min}$ compared to the normal panel.

In Figure 3 at 13:24, only the back surface was filled with water within a minute, and the output power remained higher than the reference PV for $40 \mathrm{~min}$. Maximum power was obtained at 13:28 and was increased by $6.18 \%$. The water was released from the backside container at 14:05, and the temperature of the water was around $34.4^{\circ} \mathrm{C}$. The temperature of the panel dropped from $59{ }^{\circ} \mathrm{C}$ to $35.7{ }^{\circ} \mathrm{C}$ and $56{ }^{\circ} \mathrm{C}$ to $37.6{ }^{\circ} \mathrm{C}$ in $6 \mathrm{~min}$ for the back and the front surface, respectively. Moreover, the average output power was improved by $5.4 \%$ for $30 \mathrm{~min}$ after cooling compared to the power of the reference PV panel. However, the readings after 13:55 had an error due to partial shading effect on the reference panel. Moreover, it should be noted that no devices like the I-V tracer or Maximum Point of Power Tracking (MPPT) were used, otherwise, the results would have been improved significantly like the studies in $[15,16]$. In Figure 4 , it can be noticed that cooling the backside of PV by water did not drop the panel front surface temperature significantly.

After $40 \mathrm{~min}$, the temperature of collected water from the back container was $10^{\circ} \mathrm{C}$ higher than the reservoir water temperature. However, the main reason for the cooling module being less efficient before the commencement of cooling compared to a normal panel is that it had a cover on the backside that blocked the natural ways of cooling, such as wind flow. Moreover, this design was built to eliminate thermal resistance between the coolant and the panel, and it should be on continuous cooling mode. In addition, it provided hot water to the customer; hence, it was required to repeat the cycle of cooling for the backside at a regular interval of $30 \mathrm{~min}$ on winter days during peak hours. It should be noted that whenever the backside was filled with water at ambient temperature, the efficiency was higher at least until $30 \mathrm{~min}$ compared to the non-cooled panel. Moreover, the cooling technique was intermittent, and cooling the backside consumed less energy (32\%) compared to surface cooling.

The experiments captured in Figure 3 represent typical results after several experiments. It is important to notice that back cooling experiments were conducted when there was less heat 
(from Figures 3 and 4). Back cooling was done for lower solar irradiance and lower back and surface panel temperatures compared to front and dual cooling. Since the panel power varied linearly with the irradiance and temperature degraded the panel power, we would expect the back-cooling curve (right most in Figure 3) to go up, hence exhibiting higher powers if the back cooling were done simultaneously with front and dual cooling. This might indicate that back cooling would suffice for mitigating heat effects. This can account for the fact that the solar cells substrates are sitting on the back surface of the panel, so back cooling cools the cells more quickly and more efficiently. Front cooling also does the same thing, but less efficiently, as front cooling improves efficiency by removing dust as well, which increases captured solar radiation and hence the cell's efficiency. Nonetheless, front water-cooling would have a bigger effect after long-term dust deposition on the panel surface by mainly cleaning the surface panel.

It is concluded that continuous water flow on the active surface cooling needs more time compared to the method where water is directly in contact with the back surface. The most efficient solution for cooling is suggested to be water; thus, cooling both sides by water will help to remove the dust, cool the cells down, and obtain hot water for different applications, such as domestic, healthcare, and industrial. Indeed, because of evaporation, the loss of some water is expected. However, water is easily available for these types of application because it does not require drinkable water, or during the rainy season, it can accumulate water in the trough. Thus, cooling enhances the lifespan of the module being operated at a high temperature for long periods. Overall, the above study was done over a limited period; we would expect quite a significant improvement in energy yield if this had been applied for extended periods.

It should be noted that no optimization studies were done for cooling system components' cost in this study. Nonetheless, this approach can be scaled up for a PV string or PV array, and we expect this to be economically feasible in terms of (i) hot water that could be generated from this process, (ii) the simplicity of the design with the addition of pipes, electro-mechanical valves, micro-controllers, and aluminum sheet with some efficient algorithm; and (iii) efficiency, as more energy could be generated. The investigation in this regard is a scope for future work. Table 3 presents a list of the components' prices for the proposed solution for one panel.

Table 3. List of components for the cooling system.

\begin{tabular}{clcc}
\hline Component & \multicolumn{1}{c}{ Description } & Quantity & Per Unit Price (\$) \\
\hline Aluminum sheet & \multicolumn{1}{c}{$1200 \times 530 \times 4 \mathrm{~mm}}$. & 1 & 15 \\
\hline PVC pipes & $\begin{array}{l}\text { 1/2 and 1/4-inch pipes for supplying coolant + two } \\
\text { 4-inch tubes for surface cooling + 6 elbows + 1 T } \\
\text { connecter + coupling connecters. }\end{array}$ & - & 15 \\
\hline Water tank & 250-L plastic tank. & 1 & 30 \\
\hline Electric valve & 12-V DC solenoid valves normally closed. & 3 & 5.69 \\
\hline Water pump & 24-V DC 3-phase brushless motor. & 1 & 51.29 \\
\hline Micro-controller & UNO R3 ATMega328P Arduino. & 1 & 14.8 \\
\hline Controller relays & DC 5-V coil 7-A 5-Pin SPST power relay. & 4 & 0.32 \\
\hline Total price & & & 145 \\
\hline
\end{tabular}

In order to find the economic feasibility of the solution, the below has to be considered, in a more deliberate long-run study for accurate conclusions:

- Strings or arrays of panels in a solar farm perspective.

- Cooling methodology of the arrays, which obviously should not envision one water reservoir, nor one pump or electric valve for each panel, but shared units for cost-effectiveness.

- The hot water recuperated from the arrays.

- $\quad$ Powering pumps from dedicated PV panels for cost-effectiveness. 
- The strategy in switching water electro valves on/off.

- Last, but not the least, it evidently should consider the lifetime of the solution, and hence, its total cost and gain should be calculated over its lifetime span.

\section{Conclusions}

This paper was deliberately focused on mitigating the effect of high temperature on PV system efficiency in harsh environments like Qatar and the Middle East. To this end, a proof of concept cooling system by water has been developed, and several experimental studies during peak solar radiation were carried out on back and front PV surface water-cooling. Water flow on the front and back of PV panels cleans the panels' surface by removing dust and improves the efficiency by more than $10 \%$. Furthermore, in addition to cooling PV cells, a back cooling water reservoir supplied hot water during cooling, which can be used for other applications. Since Qatar is hot for most of the year, cooling by water could be a significant solution for PV energy improvement. However, the scaling up of this approach to large-scale PV farms would require further studies in terms of cost and system optimization to assess its viability.

Author Contributions: Experiments were designed by F.T., A.I., A.K.; Experiments were performed by N.A., A.E.-T., K.B.; Results were analyzed by A.K., F.T., A.I., N.A.; All authors were involved in interpretation of data and paper writing.

Funding: The Publication of this article was funded by the Qatar National Library.

Acknowledgments: The publication of this article was funded by the Qatar National Library. The authors would like to thank the Electrical Engineering Department of Qatar University for providing the opportunity to conduct the experiments at Qatar University.

Conflicts of Interest: The authors certify that they have no affiliations with or involvement in any organization or entity with any financial interest or non-financial interest in the subject matter or materials discussed in this manuscript.

\section{References}

1. Sayyah, A.; Horenstein, M.N.; Mazumder, M.K. Energy yield loss caused by dust deposition on photovoltaic panels. Solar Energy 2014, 107, 576-604. [CrossRef]

2. Yedidi, K.; Tatapudi, S.; Mallineni, J.; Knisely, B.; Kutiche, J.; TamizhMani, G. Failure and degradation modes and rates of PV modules in a hot-dry climate: Results after 16 years of field exposure. In Proceedings of the IEEE 40th Photovoltaic Specialist Conference (PVSC), Denver, CO, USA, 8-13 June 2014; pp. 3245-3247.

3. Dorobanţu, L.; Popescu, M.; Popescu, C.; Crăciunescu, A. Experimental assessment of PV panels front water cooling strategy. Renew. Energy Pow. Qual. J. 2013, 1, 1009-1012. [CrossRef]

4. Touati, F.; Al-Hitmi, M.; Chowdhury, N.A.; Hamad, J.A.; Gonzales, A.J.S.P. Investigation of solar PV performance under Doha weather using a customized measurement and monitoring system. Renew. Energy 2016, 89, 564-577. [CrossRef]

5. Odeh, S.; Behnia, M. Improving photovoltaic module efficiency using water cooling. Heat Trans. Eng. 2009, 30, 499-505. [CrossRef]

6. Dhass, A.; Lakshmi, P.; Natarajan, E. Investigation of performance parameters of different photovoltaic cell materials using the lambert-w function. Energy Procedia 2016, 90, 566-573. [CrossRef]

7. Moharram, K.; Abd-Elhady, M.; Kandil, H.; El-Sherif, H. Enhancing the performance of photovoltaic panels by water cooling. Ain Shams Eng. J. 2013, 4, 869-877. [CrossRef]

8. Akbarzadeh, T.W.A. Heat pipe-based cooling systems for photovoltaic cells under concentrated solar radiation. Appl. Therm. Eng. 1996, 16, 81-87. [CrossRef]

9. Ullah, K.R.; Saidur, R.; Ping, H.W.; Akikur, R.K.; Shuvoc, N.H. A review of solar thermal refrigeration and cooling methods. Renew. Sustain. Energy Rev. 2013, 24, 499-513. [CrossRef]

10. Jegathala Krishnan, K. Cooling Devices for Densely Packed, High Concentration PV Arrays. Master Thesis, University of Sydney, Sydney, Australia, 2005. Available online: https:/ / folk.uio.no/anjaroy/PVCooling.pdf (accessed on 1 November 2018). 
11. Grubisic-Cabo, F.; Nizettic, S.; Giuseppe Marco, T. Photovoltaic panels: A review of the cooling techniques. Trans. FAMENA 2016, 60, 63-74.

12. Nižetić, S.; Čoko, D.; Yadav, A.; Grubišić-Čabo, F. Water spray cooling technique applied on a photovoltaic panel: The performance response. Energy Convers. Manag. 2016, 108, 287-296. [CrossRef]

13. Smith, M.K.; Selbak, H.; Wamser, C.C.; Day, N.U.; Krieske, M.; Sailor, D.J.; Rosenstiel, T.N. Water cooling method to improve the performance of field-mounted, insulated, and concentrating photovoltaic modules. J. Solar Energy Eng. 2014, 136, 034503. [CrossRef]

14. Farhana, Z.; Irwan, Y.; Azimmi, R.M.N.; Razliana, A.R.N.; Gomesh, N. Experimental investigation of photovoltaic modules cooling system. In Proceedings of the 2012 IEEE Symposium on Computers \& Informatics (ISCI), Penang, Malaysia, 18-20 March 2012.

15. Rodgers, P.; Eveloy, V. An integrated thermal management solution for flat-type solar photovoltaic modules. In Proceedings of the 2013 14th International Conference on Thermal, Mechanical and Multi-Physics Simulation and Experiments in Microelectronics and Microsystems (EuroSimE), Wroclaw, Poland, 14-17 April 2013.

16. Lowrie, D.; Rodgers, P.; Eveloy, V.; Baba, A.R. Enhancement of flat-type solar photovoltaics power generation in harsh environmental conditions. In Proceedings of the 2014 Semiconductor Thermal Measurement and Management Symposium (SEMI-THERM), San Jose, CA, USA, 9-13 March 2014.

17. Green, M.A. Third Generation Photovoltaics: Advanced Solar Energy Conversion; Springer: Berlin, Germany, 2006.

(C) 2018 by the authors. Licensee MDPI, Basel, Switzerland. This article is an open access article distributed under the terms and conditions of the Creative Commons Attribution (CC BY) license (http://creativecommons.org/licenses/by/4.0/). 